\title{
Sex dependent variations in craniofacial soft-tissue thicknesses estimated from MRI and CT scans: A pilot study based on Northwest Indian subjects
}

\author{
Kamalpreet Kaur ${ }^{1}$, Jagmahender Singh Sehrawat ${ }^{* 2}$, Rajrshi Bahadur ${ }^{3}$ \\ ${ }^{1}$ Institute of Forensic Science and Criminology, Panjab University, Chandigarh, India \\ ${ }^{2}$ Department of Anthropology, Panjab University, Chandigarh, India \\ ${ }^{3}$ Consultant Radiologist, Atulya Health Care, Chandigarh, India
}

Received: February 20, 2017

Accepted: May 9, 2017

Online Published: June 5, 2017

DOI: $10.5430 /$ ijdi.v4n2p47

URL: https://doi.org/10.5430/ijdi.v4n2p47

\begin{abstract}
Craniofacial identification is a technique for prediction and recreation of life-like appearances of an individual, recreated onto an unknown skull on the basis of intricate relationship existing between underlying bony contour and the overlying soft tissues, muscles and skin. Tissue thicknesses in different population have wide variations due to disparities in nutritional, environmental or genetical factors. The physical health, nutritional status and disease activity of an individual have significant and detectable influences on both the complex anatomy of facial skeleton as well as soft tissue depths. Present study was conducted on $50 \mathrm{MRI}$ and 53 CT normal scans of 64 male and 39 female Northwest Indian adult subjects who reported to radio-imaging diagnostic centres for some clinical and therapeutic reasons. Soft-tissue thickness was estimated at 33 craniofacial landmarks on both MRI and CT scans using OsiriX v 6.0.2 64 bit software and Digital Imaging and Communications in Medicine (DICOM) format images. MRI scans were found comparatively better and more reliable mean of estimating tissue depths and for sex estimations. Statistically significant sex differences were noticed in tissue depths at various craniofacial landmarks. The endocanthion was found the best sex discriminating variable from both types of scans. MRI and CT scan estimated tissue thicknesses could identify sex of $96 \%$ and $85 \%$, subjects, respectively. Secular increase in tissue depths was observed to support the increased trend of obesity in present day population of the area when compared with similar studies conducted few decades earlier. Present study results can be a valuable adjunct for forensic anthropological facial reconstructions and experts of diverse medical disciplines.
\end{abstract}

Key Words: Forensic anthropology, Craniofacial identification, Facial soft-tissue thickness, MRI and CT scans, Sexual differences, Northwest Indians

\section{INTRODUCTION}

Identification of unknown skulls recovered from sites of mass-disasters/genocides or crime scenes poses great challenges for forensic experts. Craniofacial reconstruction is the last option left with forensic anthropologists to identify such skull when all other conventional methods have failed in this effort. The bony skull-contour and overlying soft tissues/muscles have an intricate but complex relationship which gives a recognizable form to the face. Age, sex, race, corpulence, nutritional status, disease, activity, obesity, bodymass-index of an individual have significant influence on this relationship, in addition to some other ecological, geographical, racial and habitual conditions. ${ }^{[1-3]}$ Craniofacial morphology is the result of complex interaction between

\footnotetext{
* Correspondence: Jagmahender Singh Sehrawat, Assistant Professor; Email: jagmindera@yahoo.com; Address: Department of Anthropology, Panjab University, Chandigarh, India.
}

Published by Sciedu Press 
hereditary and environmental factors, so soft-tissue depth estimations from geographically distinct populations are required for efficient facial reconstructions. ${ }^{[4]}$ The knowledge of quantitative distribution of facial soft-tissues at different facial landmarks is a requisite factor for creating life-like recognisable features onto an unknown skull. Recreation of facial features like nose, ear, eye, lip and mouth slit from skull is very difficult, if not impossible. ${ }^{[5,6]}$

Reconstruction techniques generally rely upon the average soft-tissue depths at different anatomical landmarks suggested by different researchers for different population groups. Also, there is an increasing trend for aesthetic treatments of facial dis-morphologies, particularly by young people. The tissue depth standards may help maxillofacial orthodontic surgeons to treat facial disharmonies and the general surgeons to assess penetrance level of some malignant or non-malignant tumours in ablative surgeries. Knowledge of facial soft tissue thickness (FSTT) can be useful to locate in-depth penetration of some facial cysts, no-ablative dermal laser therapy, anthropological reconstruction of physiognomy of ancient people and forensic facial reconstruction of some facial organs/parts. Craniofacial anthropometrics is also an important mean of identifying disharmonic syndromes by the genetic counsellors. ${ }^{[7,8]}$

Bony contour and morphology of skull is almost similar in all individuals; the amount, distribution pattern and proportion of facial tissue thicknesses and musculatures at different craniofacial landmarks result in unique and recognizable facial type (convex, concave, straight) of an individual. The majority of facial anthropological research, relating to predictions of facial forms and other features from skeletal or anthropometric analyses, has been restricted to soft-tissue thickness estimations using different techniques. Facial tissue thickness varies with physical health, climatic condition, nutritional status and genetic constitution of an individual. Body-mass index (BMI) is one of important factors which influence tissue thicknesses on different body parts including facial anatomies. ${ }^{[1-3,9,10]}$ FSTT has been estimated using different techniques like needle punctures, plain radiography, computed tomography (CT), magnetic resonance imaging (MRI) and ultrasound, each of them having their own merits and demerits. ${ }^{[9]}$ The CT and MRI scans are comparatively better techniques widely used to estimate tissue-depths at different anatomical sites these days. Though MRI and CT scans are commonly used as standard protocol for clinical diagnosis and surgical treatment planning, use of these radiological methods have recently been widely accepted for forensic purposes. The recently improved versions of both these imaging modalities have significant repercussions on more accurate forensic craniofacial identifications. The CT and MRI scans allow an objective and non-evasive documentation of soft-tissue estimations of injuries and skeletal traumas11. MRI scans are comparatively better than the CT scans as the MRI based results are more satisfactory, reproducible, without any risk of radiation exposure. ${ }^{[11,12]}$

MRI utilizes the radiofrequency bands similar to FM radio waves of electromagnetic spectrum to produce images. Though, it is considered better for evaluating soft-tissues, it gives useful results for hard structures having sinuses like skull. MRI involve no exposure to ionizing radiations, ethically accepted for tissue depth estimations and it is proved to be a fast, non-ionizing tool increasingly used to document forensic findings to pursue extensive research with larger sample sizes. ${ }^{[13]}$ The application of improved radio-imaging technological inputs in forensic identifications has increased manifold in last two decades. Such methods don't require any skeletal preparation, have no fear of bone damage or deterioration and have potentiality to identify even the living individuals. ${ }^{[14]}$ Both CT and MRI present a permanent record to be reanalysed and rechecked at any time since they are based on digital images, easy to manipulate, to verify paired landmark measurements, to obtain longitudinal data and without any soft-tissue compressions. Soft tissue thickness measurements have multiple diagnostic, clinical, anthropological and forensic applications such as in craniofacial reconstructions, plastic surgeries, orthodontic maxillofacial adjustments, evaluating penetration of malignant or non-malignant facial tumours etc.

Present study was conducted to provide mean soft-tissue depth standards for different anatomical landmarks in two sexes using both MRI and CT scans. The main aim of present study was to propose soft-tissue estimates for a Northwest Indian population to be used by experts of different medical, forensic and anthropological specialities with following objectives:

- To give comparative analysis of soft-tissue thicknesses at various craniofacial landmarks.

- To assess comparative utility of MRI or CT scans in estimating facial soft-tissue thicknesses.

- To estimate sex and BMI dependent variations in softtissue estimates.

- To highlight any secular changes in tissue depths at various facial landmarks.

\section{MATERIALS AND METHODS}

Present study was conducted on $50 \mathrm{MRI}$ and $53 \mathrm{CT}$ scans of 103 Northwest Indian subjects (64 Males and 39 Females between 18-90 years) belonging to states of Punjab, Haryana, Himachal Pradesh and Union Territory of Chandigarh (In- 
dia), who reported to the radio-diagnostic centres for radioimaging of their head and facial regions for therapeutic and diagnostic reasons during first half of the year 2015. Ethical clearance was obtained from Panjab University Institutional Ethics Committee (PUIEC/2015/13/1-A/17/09) to carry this study and a prior well-informed written consent was taken from each subject for forensic anthropological examination of his/her MRI and CT scans. Present study data is based on a pilot study planned for a definite period of time to have an idea about any sexual and secular differences in tissue thicknesses in individuals of a Chandigarh region of India. A patient had been referred to the diagnostic centre either for his/her MRI or CT scans.

Demographic information such as sex, age, height, weight and ethnic attribution of the subjects, along with their facial tissue thickness estimates were recorded in a pre-structured proforma. Soft tissue thickness was measured as the distance between specific landmarks on the bone relative to the surface of soft-tissue in the scan. 33 craniofacial landmarks (16 midline points and 17 bilateral points, thus totalling at 50 points) were selected on the MRI or CT scan of the subject. MRI and CT scans belonged to different persons and no two scans of the same person were included in the study. The names and definitions of various mid-line and bilateral craniofacial landmarks have been described in Table 1 and shown in Figure 1. The tissue thicknesses were measured using Osiris v 6.0.2 64 bit software. Patients with any metallic implants, facial deformity, skin disorder, previous facial fractures, malformations, asymmetries etc., which could possibly affect tissue-thickness estimates and facial profile, were excluded from study. The axial, sagittal and coronal $\mathrm{T} 1$ weighted images were obtained in Digital Imaging and Communications in Medicine (DICOM) format for each subject.

Table 1. Mid-facial and Bilateral craniofacial landmarks (with their definitions) considered for tissue depth estimations in present study

\begin{tabular}{|c|c|c|}
\hline Number & Craniofacial landmark & Definition \\
\hline & Mid-facial & \\
\hline 1 & Supra-glabella (sg) & Most anterior point of the forehead, above the glabella in the mid-sagittal plane \\
\hline 2 & Glabella (g) & Most prominent anterior point of the forehead, between supraorbital crests \\
\hline 3 & Metopian (m) & Median point of line connecting two frontal eminences \\
\hline 4 & Nasion (n) & A point of intersection of internasal suture and frontonasal suture \\
\hline 5 & Rhinion (r) & Point at end of nasal bone (lowest free end of inter-nasal suture in the mid-sagittal plane) \\
\hline 6 & Pronasale (pr) & Most anterior point on tip of the nose \\
\hline 7 & Subnasal (sn) & A point where margin of nasal septum meets integument of upper lip \\
\hline 8 & Mid philtrum (mp) & $\begin{array}{l}\text { A point at midline of the maxilla, placed as high as possible before the curvature of the anterior nasal spine } \\
\text { begin }\end{array}$ \\
\hline 9 & Labile superius (ls) & A point at upper margin of integumental lip in midline \\
\hline 10 & Labile inferious (li) & A midline point at the most anterior edge on the alveolar edge of maxilla \\
\hline 11 & Incisor superius (is) & Most anterior midline point at level of the incisor crown \\
\hline 12 & Supradentale (sd) & A point centred between the maxillary central incisors at the level of the cementum-enamel junction \\
\hline 13 & Infradentale (if) & A point centred between the mandibular central incisors at the level of the cementum-enamel junction \\
\hline 14 & Pogonion (po) & Most prominent point in the midline of the mental protuberance \\
\hline 15 & Supragnathion (sgn) & Most antero-inferior midline point of the mental eminence between pogonion and gnathion \\
\hline \multirow[t]{2}{*}{16} & Gnathion (gn) & The Lowest point on the lowest border of the mandible in the mid-sagittal plane \\
\hline & Bilateral & \\
\hline 17 & Frontal eminences (fe-fm) & A point on projection at both sides of forehead \\
\hline 18 & Fronto temporal (ft-fl) & Most interior and inner point on frontal bone \\
\hline 19 & Orbitale (or-ol) & Most inferior point on orbital rim \\
\hline 20 & Supra orbitale (so-sa) & Point centred on upper margin of orbit \\
\hline 21 & Sub orbitale (sr-sb) & Point centred on lower margin of orbit \\
\hline 22 & Ectocanthion (ec-el) & Point on the lateral corner of the eye \\
\hline 23 & Endocanthion (ed-eo) & Point on the medial corner of the eye \\
\hline 24 & Superciliare point (sp-sl) & Most anterior point of super-ciliary arch in centre of orbit \\
\hline 25 & Zygion (zr-zl) & Most lateral point on the zygomatic arch \\
\hline 26 & Zugale (z-zn) & The deepest point of the zygomaxillary suture \\
\hline 27 & Supraglenoid (se-su) & Point at the root of the zygomatic arch just before the ear \\
\hline 28 & Condylion (cn-cl) & Most lateral point of the glenoid process of mandible \\
\hline 29 & Occlusal line (og-on) & A point in the extremity of the anterior portion of mandibular ramus at the horizontal level of chelion \\
\hline 30 & Supra $\mathrm{M}^{2}$ (sm-sh) & A point located in the alveolar process at the level of the middle of the second upper molar \\
\hline 31 & Sub $\mathrm{M}_{2}$ (sj-sk) & A point located in the alveolar process at the level of the middle of the second lower molar \\
\hline 32 & Chelion (c-ce) & This corresponds to the labile commissure or corners of mouth opening \\
\hline 33 & Gonion (gr-gl) & $\begin{array}{l}\text { A point located in the jaw line at the level of the angle between the posterior with the inferior borders of the } \\
\text { mandible }\end{array}$ \\
\hline
\end{tabular}




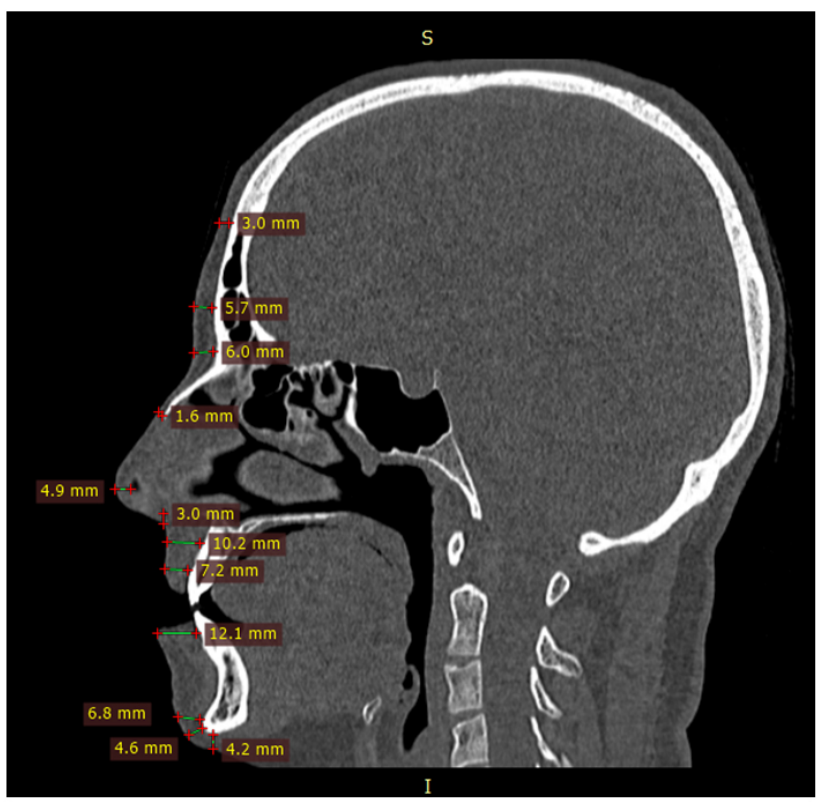

Figure 1. Estimation of soft-tissue depths at different craniofacial landmarks using CT scans

\subsection{Technical specifications of MRI and CT scanners}

Siemens Espree 1.5T wide bore whole body MR Scanner, 'Magnetom Espree', FoV (Field of view) $=230-250$, TR $($ Total resolution $)=1390-10,000 \mathrm{~ms}$, Matrix $=256 \times 256$, Slice thickness $=1 \mathrm{~mm}$, TE $($ total enhancement $)=219 \mathrm{~ms}$, Slabs $=70-90$, slices $/$ slab $=75$ to 90 , Distance factor (difference between per slab) $=50 \%$ (MRI Scanner) Somatom Defination 64 Dual Source, Siemnes, Image thickness $=0.75$ $\mathrm{mm}$, Image index $=0.7 \mathrm{~mm}$, Window width $=2,000$, Window level $=400$, Pixels $=512 \times 512$, Scan mode $=$ helical $(\mathrm{CT}$ scanner)

\subsection{Statistical applications}

The data was inserted into Microsoft excel spread-sheet and; descriptive statistics like mean, standard deviation, CV were calculated for tissue thicknesses at each landmark using both modalities and univariate and multivariate discriminant function analyses were run using IBM SPSS (Statistical Package for Social Sciences) version 21.0 software ${ }^{[15]}$ to select the best variables to discrimate the sex of the subjects whose scans were used.

\section{RESUlts}

The name and definition of various bilateral and mid-facial landmarks at which soft-tissue thicknesses were estimated in present study have been given in Table 1. The mean tissue thicknesses estimated in two sexes from both MRI and CT scans have been presented in Table 2 which shows that almost all craniofacial variables showed sexual differences using both radiographic modalities (MRI and CT scans). Statistically significant sexual differences were observed at 22 anatomical points in MRI images, 23 points using CT scans and at 45 landmarks from both MRI and CT scans (see Table 3). On an average, male subjects had greater soft-tissue thickness at almost all points, though females had higher mean tissue thicknesses at some anatomical points like gonion, rhinion, subnasale, chelion (right), ecto- and endocanthion (right) in MRI scans, and at left endocanthion, right zygion, right zugale and right condylion points in CT scans. The highest sexual dimorphism in soft tissue differences was observed at points right and left $\mathrm{Sub} \mathrm{M}_{2}$, right and left gonion points from both MRI and CT scans; and at right occlusal line from MRI scans only.

Table 3 describes the mean values of soft tissue thicknesses estimated from MRI and CT scans without discriminating between two sexes. It has been observed that from MRI scans, most of upper facial landmarks (supra-glabella, glabella, nasion, metopion, rhinion, mid-philtrum and labiale superious) have higher values than those estimated from CT scans. Similarly CT scans showed higher tissue thicknesses for lower facial landmarks like Gnathion, supragnathion, pogonion and infradentale, but statistically significant differences were noticed for Gnathion and subnasale points only. Labiale superious had significant differences in individual sexes also.

From the stepwise multivariate discriminant function analysis (MDFA) of soft tissue thicknesses estimated from MRI only, it was found that out of 50 variables; only 3 variables (pronasale, endocanthion-right, chelion-left) were selected as the best landmarks to discriminate the sex of $98 \%$ subjects (96.8\% males and $100 \%$ females) from the original grouped data and $96 \%$ subjects (93.5\% males and $100 \%$ females) from cross-validated data (see Tables 4 and 5). Similarly, from the stepwise MDFA of soft tissue thicknesses measured from CT scans (see Tables 5 and 6), it was found that out of 50 variables only 4 variables (mid-philtrum, gonionleft, zugale-right, endocanthion-right) were selected as best variables to discriminate the sex of $84.9 \%$ subjects $(84.8 \%$ males and $85.0 \%$ females) from the original grouped data and $81.1 \%$ subjects ( $84.8 \%$ males and $75 \%$ females) from cross-validated data. Right endocanthion was selected as best variables to discriminate sex of an individual from both MRI and CT scan variables. Table 7 shows the discriminant function equations for sex estimations fromtissue depth estimates from the CT and MRI scans. By inserting the values of anatomical landmarks in the equations given in Table 7 , the sex of the unknown head/skull can be determined and compared with sex-specific group centroid e.g. from MRI, if calculated value is near to 0.750 , then subject is male and if value is near to -1.224 that subject is female. Similarly, in 
case of CT scans, if calculated value is near to 0.872 then ation levels. ${ }^{[12]}$ As shown in Tables 5 and 8 , if we analyse subject is male and if value is near to -1.438 she is a female. the data concurrently (without discriminating between MRI The MRI scan was found statistically a better, reliable and and CT), sex of $88.3 \%$ subjects (87.5\% males and $89.7 \%$ more accurate technique of estimating sex of an unknown females) was identified correctly. Eigen value and canonical individual than the CT scans. MRI has been strongly advo- correlation for MRI is 0.957 and 0.699 , and for CT 1.302 cated for soft-tissue observations, being a noncontact method and 0.752 respectively. It was found that eigenvalue and that enables measurement on living subjects with low radi- canonical correlation of CT is more as compared to MRI.

Table 2. Mean soft-tissue depths estimated from MRI and CT scans in two sexes

\begin{tabular}{|c|c|c|c|c|c|c|}
\hline \multirow{2}{*}{ Variable } & \multicolumn{2}{|c|}{ MEAN \pm S.D (MRI), N = 50} & \multirow{2}{*}{$\begin{array}{l}\text {-test with } \\
\text { significance }\end{array}$} & \multicolumn{2}{|c|}{ MEAN \pm S.D (CT), N = 53} & \multirow{2}{*}{$\begin{array}{l}t \text {-test with } \\
\text { significance }\end{array}$} \\
\hline & Male $(\mathrm{n}=31)$ & Female $(n=19)$ & & Male $(n=33)$ & Female $(n=20)$ & \\
\hline Metopian (m) & $5.62 \pm 1.51$ & $4.62 \pm 1.05$ & $2.773^{* *}$ & $4.17 \pm 1.16$ & $3.61 \pm 0.99$ & $1.855^{*}$ \\
\hline Pronasale (pr) & $4.87 \pm 1.01$ & $3.80 \pm 0.77$ & $4.233^{* *}$ & $4.23 \pm 1.35$ & $3.52 \pm 1.07$ & $2.108^{*}$ \\
\hline Mid philtrum (mp) & $13.00 \pm 2.99$ & $10.56 \pm 2.92$ & $2.852 * *$ & $6.56 \pm 2.00$ & $5.36 \pm 1.07$ & $2.837 * *$ \\
\hline labiale superius (ls) & $12.51 \pm 3.23$ & $9.54 \pm 3.36$ & $3.084^{* *}$ & $4.87 \pm 1.34$ & $3.97 \pm 0.91$ & $2.899 * *$ \\
\hline Labile inferious (li) & $10.18 \pm 2.82$ & $8.55 \pm 2.77$ & $2.005^{*}$ & $12.26 \pm 2.55$ & $9.11 \pm 2.05$ & $4.945^{* *}$ \\
\hline Incisor superius (is) & $8.18 \pm 1.97$ & $6.22 \pm 1.26$ & $4.298^{* *}$ & $9.04 \pm 2.95$ & $7.33 \pm 1.81$ & $2.620^{*}$ \\
\hline Supradentale (sd) & $8.33 \pm 2.00$ & $6.33 \pm 1.11$ & $4.518^{* *}$ & $8.04 \pm 2.46$ & $6.66 \pm 1.51$ & $2.527 *$ \\
\hline Infradentale (if) & $8.98 \pm 2.25$ & $6.87 \pm 1.81$ & $3.632 * *$ & $11.48 \pm 1.95$ & $9.77 \pm 2.51$ & $2.601^{*}$ \\
\hline Gnathion (gn) & $5.90 \pm 2.06$ & $4.95 \pm 1.71$ & $1.827^{*}$ & $9.29 \pm 2.69$ & $7.82 \pm 2.84$ & $1.866^{*}$ \\
\hline Right Frontal eminences (fe) & $6.46 \pm 1.84$ & $5.63 \pm 1.41$ & $1.790 *$ & $4.88 \pm 1.48$ & $4.23 \pm 1.27$ & $1.693^{*}$ \\
\hline Left Frontal eminences (fm) & $6.46 \pm 1.85$ & $5.55 \pm 1.45$ & $1.944^{*}$ & $7.84 \pm 1.58$ & $6.98 \pm 1.43$ & $2.038^{*}$ \\
\hline Left Superciliare point (sl) & $8.94 \pm 1.77$ & $7.53 \pm 1.78$ & $2.735 * *$ & $7.80 \pm 1.43$ & $6.76 \pm 1.09$ & $2.997 * *$ \\
\hline Left supra-glenoid (su) & $16.79 \pm 3.17$ & $15.34 \pm 2.83$ & $1.687^{*}$ & $25.60 \pm 4.20$ & $21.96 \pm 4.11$ & $3.105^{* *}$ \\
\hline Right occlusal line (og) & $27.73 \pm 5.95$ & $22.78 \pm 5.22$ & $3.082^{* *}$ & $25.48 \pm 4.12$ & $22.45 \pm 4.16$ & $2.580^{*}$ \\
\hline Left occlusal line (on) & $27.27 \pm 5.37$ & $22.53 \pm 5.20$ & $3.096^{* *}$ & $31.02 \pm 6.18$ & $28.17 \pm 5.19$ & $1.803^{*}$ \\
\hline Right Supra $\mathrm{M}^{2}$ (sm) & $30.62 \pm 5.55$ & $26.66 \pm 5.07$ & $2.584^{*}$ & $31.81 \pm 6.04$ & $28.73 \pm 5.29$ & $1.948^{*}$ \\
\hline Left Supra M² (sh) & $30.47 \pm 4.88$ & $26.92 \pm 4.75$ & $2.540 *$ & $27.71 \pm 5.39$ & $23.05 \pm 5.15$ & $3.137 *$ \\
\hline Right Sub $\mathrm{M}_{2}$ (sj) & $27.30 \pm 4.67$ & $22.90 \pm 5.70$ & $2.835^{* *}$ & $27.64 \pm 5.43$ & $23.64 \pm 5.40$ & $2.613^{*}$ \\
\hline Left Sub $\mathrm{M}_{2}$ (sk) & $27.62 \pm 4.56$ & $23.22 \pm 6.07$ & $2.722^{*}$ & $7.69 \pm 1.86$ & $6.13 \pm 1.41$ & $3.445^{* *}$ \\
\hline Left Chelion (се) & $7.04 \pm 1.36$ & $5.19 \pm 1.10$ & $5.282^{* *}$ & $8.47 \pm 5.11$ & $6.21 \pm 1.42$ & $2.396^{*}$ \\
\hline Right Gonion (gr) & $23.48 \pm 6.03$ & $19.93 \pm 6.22$ & $1.983^{*}$ & $25.46 \pm 6.01$ & $18.02 \pm 6.68$ & $4.081^{* *}$ \\
\hline
\end{tabular}

$* p<.05, * * p<.001$

Table 3. Mean tissue thicknesses estimated from MRI and CT scans (both sexes combinedly)

\begin{tabular}{|c|c|c|c|c|c|c|c|}
\hline \multirow{2}{*}{ Landmark } & \multicolumn{3}{|c|}{ MRI Scan (N = 50) } & \multicolumn{3}{|c|}{ CT Scan $(N=53)$} & \multirow{2}{*}{ t-test } \\
\hline & Mean & Std. Error & Variance & Mean & Std. Error & Variance & \\
\hline Supra-glabella (sg) & $4.84 \pm 0.91$ & .128 & .82 & $3.96 \pm 1.22$ & .154 & 1.26 & -4.403 \\
\hline Metopian (m) & $5.24 \pm 1.43$ & .20246 & 2.05 & $3.96 \pm 1.29$ & .177 & 1.65 & -4.759 \\
\hline Nasion (n) & $6.86 \pm 1.82$ & .257 & 3.29 & $6.11 \pm 1.79$ & .246 & 3.22 & -2.096 \\
\hline Rhinion (r) & $3.28 \pm 1.15$ & .162 & 1.31 & $2.36 \pm 2.10$ & .289 & 4.42 & -2.758 \\
\hline Pronasale (pr) & $4.46 \pm 1.06$ & .149 & 1.12 & $4.53 \pm 1.27$ & .174 & 1.61 & 0.307 \\
\hline Subnasal (sn) & $4.01 \pm 1.54$ & .218 & 2.38 & $5.49 \pm 2.57$ & .353 & 6.63 & $3.579 * *$ \\
\hline Mid philtrum (mp) & $12.07 \pm 3.17$ & .448 & 10.07 & $11.08 \pm 2.81$ & .386 & 7.90 & -1.686 \\
\hline Labile superius (ls) & $11.38 \pm 3.56$ & .503 & 12.64 & $8.39 \pm 2.69$ & .369 & 7.24 & -4.793 \\
\hline Labile inferious (li) & $9.56 \pm 2.89$ & .408 & 8.33 & $9.04 \pm 2.63$ & .362 & 6.93 & -0.961 \\
\hline Incisor superius (is) & $7.43 \pm 1.97$ & .279 & 3.88 & $7.52 \pm 2.24$ & .308 & 5.03 & -0.210 \\
\hline Supradentale (sd) & $7.57 \pm 1.97$ & .278 & 3.86 & $8.07 \pm 2.16$ & .296 & 4.66 & 1.226 \\
\hline Pogonion (po) & $8.78 \pm 2.56$ & .362 & 6.54 & $10.84 \pm 2.31$ & .318 & 5.35 & 4.265 \\
\hline Supragnathion (sgn) & $6.05 \pm 1.93$ & .273 & 3.72 & $8.73 \pm 2.81$ & .386 & 7.90 & 5.685 \\
\hline Gnathion (gn) & $5.57 \pm 1.98$ & .279 & 3.91 & $7.14 \pm 3.39$ & .466 & 11.5 & $2.889 *$ \\
\hline
\end{tabular}

$* p<.05, * * p<.001$ 
Table 4. Classification functions for discrimination of sex from MRI scan based tissue-depth estimations

\begin{tabular}{|c|c|c|c|c|c|c|c|}
\hline \multirow{2}{*}{$\begin{array}{l}\text { Variable } \\
\text { selected }\end{array}$} & \multirow[b]{2}{*}{ Tolerance } & \multirow{2}{*}{$\begin{array}{l}\text { F to } \\
\text { Remove }\end{array}$} & \multirow{2}{*}{$\begin{array}{l}\text { Wilks } \\
\text { Lambda }\end{array}$} & \multirow[b]{2}{*}{ SCDFC } & \multirow{2}{*}{$\begin{array}{l}\text { CDFC } \\
\text { Constant }=-7.360\end{array}$} & \multicolumn{2}{|c|}{ Fisher's Linear Discriminant Functions } \\
\hline & & & & & & $\begin{array}{l}\text { Males* } \\
\text { Constant = -31.605 }\end{array}$ & $\begin{array}{l}\text { Females } * * \\
\text { Constant }=-19.77\end{array}$ \\
\hline $\mathrm{pr}$ & 0.989 & 6.273 & 0.581 & 0.498 & 0.536 & 4.918 & 3.860 \\
\hline sd & 0.961 & 4.441 & 0.560 & 0.433 & 0.251 & 2.119 & 1.623 \\
\hline се & 0.959 & 9.913 & 0.621 & 0.615 & 0.484 & 3.506 & 2.552 \\
\hline
\end{tabular}

Note. SCDFC = Standardized canonical discriminant function coefficients; CDFC = Canonical discriminant function coefficients;

*Male group centroid $=0.750 ; * *$ Female group centroid $=-1.224$.

Table 5. Stepwise multivariate discriminant function results for sex determination

\begin{tabular}{|c|c|c|c|c|c|}
\hline \multirow{2}{*}{ Method } & \multirow{2}{*}{$\begin{array}{l}\text { Originally } \\
\text { grouped/cross-validated }\end{array}$} & \multirow{2}{*}{ SEX } & \multicolumn{2}{|c|}{ Predicted Group Membership (\%) } & \multirow{2}{*}{$\begin{array}{l}\text { Overall Correct } \\
\text { Classification (\%) }\end{array}$} \\
\hline & & & MALE & FEMALE & \\
\hline \multirow{4}{*}{ MRI } & \multirow{2}{*}{ Original } & $\mathrm{M}$ & 96.8 & 3.2 & \multirow{2}{*}{98.0} \\
\hline & & $\mathrm{F}$ & 0 & 100 & \\
\hline & \multirow{2}{*}{ Cross validated } & $\mathrm{M}$ & 93.5 & 6.5 & \multirow{2}{*}{96.0} \\
\hline & & $\mathrm{F}$ & 0 & 100 & \\
\hline \multirow{4}{*}{$\mathrm{CT}$} & \multirow{2}{*}{ Original } & $\mathrm{M}$ & 84.8 & 15.2 & \multirow{2}{*}{84.9} \\
\hline & & $\mathrm{F}$ & 15.0 & 85.0 & \\
\hline & \multirow{2}{*}{ Cross validated } & $\mathrm{M}$ & 84.8 & 15.2 & \multirow{2}{*}{81.1} \\
\hline & & $\mathrm{F}$ & 25.0 & 75.0 & \\
\hline \multirow{4}{*}{$\begin{array}{l}\text { Both MRI and } \\
\text { CT }\end{array}$} & \multirow{2}{*}{ Original } & $\mathrm{M}$ & 87.5 & 12.5 & \multirow{2}{*}{88.3} \\
\hline & & $\mathrm{F}$ & 10.3 & 89.7 & \\
\hline & \multirow{2}{*}{ Cross validated } & M & 85.9 & 14.1 & \multirow{2}{*}{84.5} \\
\hline & & $\mathrm{F}$ & 17.9 & 82.1 & \\
\hline
\end{tabular}

Table 6. Classification functions for discrimination of sex from CT scan based tissue-depth estimations

\begin{tabular}{|c|c|c|c|c|c|c|c|}
\hline \multirow{2}{*}{$\begin{array}{l}\text { Variable } \\
\text { selected }\end{array}$} & \multirow[b]{2}{*}{ Tolerance } & \multirow{2}{*}{$\begin{array}{l}\text { F to } \\
\text { Remove }\end{array}$} & \multirow{2}{*}{$\begin{array}{l}\text { Wilks } \\
\text { Lambda }\end{array}$} & \multirow[b]{2}{*}{ SCDFC } & \multirow{2}{*}{$\begin{array}{l}\text { CDFC } \\
\text { Constant }=-\mathbf{6 . 0 7 9}\end{array}$} & \multicolumn{2}{|c|}{ Fisher's Linear Discriminant Functions } \\
\hline & & & & & & $\begin{array}{l}\text { Males* } \\
\text { Constant = }-31.605\end{array}$ & $\begin{array}{l}\text { Females** } \\
\text { Constant }=-\mathbf{1 8 . 2 2 0}\end{array}$ \\
\hline $\mathrm{mp}$ & 0.846 & 19.541 & 0.611 & 0.777 & 0.328 & 2.552 & 1.796 \\
\hline ed & 0.724 & 7.547 & 0.503 & 0.576 & 0.438 & 4.383 & 3.371 \\
\hline $\mathrm{z}$ & 0.589 & 16.504 & 0.584 & -0.876 & -0.276 & -1.104 & -.468 \\
\hline gl & 0.731 & 19.878 & 0.614 & 0.841 & 0.137 & 0.905 & .587 \\
\hline
\end{tabular}

Note. SCDFC = Standardized canonical discriminant function coefficients; CDFC = Canonical discriminant function coefficients;

*Male group centroid $=0.872 ; * *$ Female group centroid $=-1.438$.

Table 7. Discriminant function equations

\begin{tabular}{llll}
\hline \multirow{2}{*}{ Modality } & \multicolumn{2}{l}{ Canonical discriminant function equations for Sex estimation } & \\
\cline { 2 - 4 } & If sex is Unknown & If sex is Male & If sex is Female \\
\hline \multirow{2}{*}{ MRI } & $D F:$ & $D F:$ & $D F:$ \\
& $-7.360+0.536(\mathrm{pr})+0.251(\mathrm{sd})+0.484(\mathrm{ce})$ & $-33.841+4.918(\mathrm{pr})+2.119(\mathrm{sd})+3.509(\mathrm{ce})$ & $-19.777+3.860(\mathrm{pr})+1.623(\mathrm{sd})+2.552(\mathrm{ce})$ \\
& $D F:$ & $D F:$ & $D F:$ \\
CT & $-6.079+0.328(\mathrm{mp})+0.438(\mathrm{ed})-0.276(\mathrm{z})+$ & $-31.605+2.552(\mathrm{mp})+4.383(\mathrm{ed})-1.104(\mathrm{z})$ & $-18.220+1.796(\mathrm{mp})+3.371(\mathrm{ed})-0.468(\mathrm{z})+0.58$ \\
& $0.137(\mathrm{gl})$ & $+0.905(\mathrm{gl})$ & $7(\mathrm{gl})$ \\
\hline
\end{tabular}

Body-mass index (BMI) could be estimated only for 42 sub- $\quad$ (42.9\%) or fourth (38.1\%) group of classification. No statistijects and it was classified into four groups according to WHO cal significant relationship was noticed between BMI/obesity standards. It was found that majority of subjects fall into third and tissue thicknesses, so it was neglected for further foren- 
sic anthropological examinations. This may be due to small individual play crucial role in facial tissue thicknesses variasample size of BMI estimates due to the fact that only 42 tions among South Indians and it should be kept in mind by subjects allowed the author to record their height and weight. practitioners to calculate tissue depths in individual cases.

Kotrashetti and Mallapur ${ }^{[10]}$ found that sex and BMI of an

Table 8. Classification functions for discrimination of sex without distinction between MRI or CT based tissue-depth estimations

\begin{tabular}{|c|c|c|c|c|c|c|c|}
\hline \multirow[b]{2}{*}{$\begin{array}{l}\text { Variable } \\
\text { selected }\end{array}$} & \multirow[b]{2}{*}{ Tolerance } & \multirow[b]{2}{*}{$\begin{array}{l}\text { F to } \\
\text { Remove }\end{array}$} & \multirow[b]{2}{*}{$\begin{array}{l}\text { Wilks } \\
\text { lambda }\end{array}$} & \multirow[b]{2}{*}{ SCDFC } & \multirow[b]{2}{*}{$\begin{array}{l}\text { CDFC } \\
\text { Constant }=-6.168\end{array}$} & \multicolumn{2}{|c|}{ Fisher's Linear Discriminant Functions } \\
\hline & & & & & & $\begin{array}{l}\text { Males* } \\
\text { Constant }=-41.121\end{array}$ & $\begin{array}{l}\text { Females** } \\
\text { Constant }=-27.179\end{array}$ \\
\hline $\mathrm{g}$ & 0.678 & 0.013 & 0.455 & $\begin{array}{l}-0.408 \\
\end{array}$ & -0.298 & 0.841 & 1.548 \\
\hline pr & 0.936 & 0.046 & 0.445 & 0.282 & 0.264 & 3.435 & 2.809 \\
\hline $\mathrm{mp}$ & 0.690 & 0.056 & 0.443 & 0.315 & 0.116 & 0.460 & 0.184 \\
\hline is & 0.875 & 0.002 & 0.471 & 0.439 & 0.225 & 1.915 & 1.382 \\
\hline $\mathrm{fl}$ & 0.566 & 0.035 & 0.447 & -0.381 & -0.083 & 0.266 & 0.463 \\
\hline sl & 0.427 & 0.000 & 0.488 & 0.722 & 0.446 & 3.170 & 2.114 \\
\hline $\mathrm{zl}$ & 0.473 & 0.015 & 0.455 & -0.483 & -0.151 & -1.120 & -0.763 \\
\hline $\mathrm{z}$ & 0.386 & 0.000 & 0.499 & -0.815 & -0.241 & -1.441 & -0.869 \\
\hline og & 0.362 & 0.005 & 0.464 & 0.627 & 0.126 & 0.938 & 0.640 \\
\hline gr & 0.543 & 0.005 & 0.465 & 0.519 & 0.084 & 0.145 & -0.053 \\
\hline
\end{tabular}

Note. SCDFC = Standardized canonical discriminant function coefficients; $\mathrm{CDFC}=$ Canonical discriminant function coefficients;

$*$ Male group centroid $=0.898 ; * *$ Female group centroid $=-1.473$.

\section{Discussions}

Knowledge of facial soft tissue thickness is also useful to locate in-depth penetration of malignant or non-malignant facial tumors, no-ablative dermal laser therapy, anthropological reconstruction of ancient people etc. Tissue depth standards may help to plan and execute reconstructive surgeries by orthopedicians or surgeons or to treat any congenital or post-traumatic facial disharmonies by aesthetic maxillofacial surgeons, besides their forensic applications. Few studies have been conducted for soft-tissue thickness estimations in Indian context, particularly from MRI and CT scans of the living individuals. Sachan et al. ${ }^{[16]}$ estimated soft tissue thicknesses from cephalograms of North Indian faces and reported sexual dimorphism at some craniofacial landmarks, cautioning orthodontists and surgeons to use sex and population specific tissue reference values in their routine work. Statistically significant sex and BMI dependent differences in soft-tissue thicknesses have also been reported Sahni et al. ${ }^{[11,12]}$ for this heterogeneous population group more than a decade earlier. Saxena et al. ${ }^{[17]}$ found that tissue depths were lesser in females than the males which decrease with age, except at mandibular ramus level, but no bilateral differences were noticed in tissue depths from CT scan based tissue depth estimates. ${ }^{[17]}$

Identity establishment of skeletonized human remains is somewhat more difficult. Forensic facial approximation is

Published by Sciedu Press the last option left with a forensic anthropologist entrusted to identify such remains when other means of identification fail. ${ }^{[7]}$ Facial reconstruction involves construction of faces on unknown skull with inputs from the relatives or accomplices about morphological facial features of the deceased. Facial reconstruction is a both a science as well as art which attempts to recreate likeness of victim's face or recognition from a skull or its cast by drawing, sculpture or computer assisted methods. Accurate facial reconstruction requires knowledge of the approximate soft tissue thicknesses at various craniofacial landmarks. ${ }^{[2]}$ To perform facial reconstruction sets of average craniometrics measurements and soft tissue thicknesses at pre-determined anatomical landmarks are used.

Craniometrics measurements and soft tissue thickness measurements are different for the different populations and they vary between two sexes, between age groups and also change with the nutritional status, diseased condition, physical conditions etc. Statistically relevant measurements of the soft tissue thickness at different anatomical points of face impart vital information for the reconstruction of acceptable and accurate facial images in forensics. In recent times, the development of advanced radio-imaging diagnostic techniques like ultrasonography, CT and MRI scanning has made it possible to access living subject data. 
Table 9 shows that for Northwest Indians, facial tissue thicknesses showed secular increases at upper facial points (glabella, supraglabella, nasion, rhinion and mid-philtrum) whereas lower facial points like Gnathion, mental prominence and lower lip margins showed a decreasing trend. Similar trends were noticed when tissue thicknesses were compared with Chinese subjects studied by Chen et al. ${ }^{[18]}$
Turkish, Prague and South Indian people have higher facial tissue depths at almost all points when compared with Northwest Indians of present study. ${ }^{[10,19,20]}$ These differences may be due to different genetic or environmental conditions and can play significant role in forensic facial reconstructions, if we know the ethnic attribution of unknown skull found at the crime scene.

Table 9. Comparative analysis of soft-tissue thicknesses at same craniofacial landmarks by different researchers in different populations

\begin{tabular}{|c|c|c|c|c|c|c|c|c|c|c|c|c|}
\hline \multirow{3}{*}{$\begin{array}{l}\text { Anatomical } \\
\text { Landmark }\end{array}$} & \multicolumn{2}{|c|}{ Present study (2016) } & \multicolumn{2}{|c|}{ Sahni et al. (2009) } & \multicolumn{2}{|c|}{ Chen et al. (2011) } & \multicolumn{2}{|c|}{ Sipahioglu (2012) } & \multicolumn{2}{|c|}{ Drgacova et al. (2016) } & \multicolumn{2}{|c|}{$\begin{array}{l}\text { Kotrashetti and } \\
\text { Mallapur (2016) }\end{array}$} \\
\hline & \multicolumn{2}{|c|}{ Northwest Indians } & \multicolumn{2}{|c|}{ Northwest Indians } & \multicolumn{2}{|l|}{ Chinese } & \multicolumn{2}{|l|}{ Turkish } & \multicolumn{2}{|c|}{ Prague (Czeck Republic) } & \multicolumn{2}{|c|}{ South Indian } \\
\hline & $\begin{array}{l}\text { Male } \\
(\mathrm{N}=64)\end{array}$ & $\begin{array}{l}\text { Female } \\
(\mathrm{N}=39)\end{array}$ & $\begin{array}{l}\text { Male } \\
(\mathrm{N}=173)\end{array}$ & $\begin{array}{l}\text { Female } \\
(N=127)\end{array}$ & $\begin{array}{l}\text { Male } \\
(\mathrm{N}=233)\end{array}$ & $\begin{array}{l}\text { Female } \\
(\mathrm{N}=192)\end{array}$ & $\begin{array}{l}\text { Male } \\
(\mathrm{N}=79)\end{array}$ & $\begin{array}{l}\text { Female } \\
(\mathrm{N}=82)\end{array}$ & $\begin{array}{l}\text { Male } \\
(\mathrm{N}=56)\end{array}$ & $\begin{array}{l}\text { Female } \\
(N=46)\end{array}$ & $\begin{array}{l}\text { Male } \\
(\mathrm{N}=152)\end{array}$ & $\begin{array}{l}\text { Female } \\
(N=156)\end{array}$ \\
\hline Supraglabella & $\begin{array}{l}4.54 \pm \\
1.12\end{array}$ & $\begin{array}{l}4.13 \pm \\
1.07\end{array}$ & $\begin{array}{l}3.44 \pm \\
0.36\end{array}$ & $\begin{array}{l}3.57 \pm \\
0.40\end{array}$ & $\begin{array}{l}3.98 \pm \\
0.71\end{array}$ & $\begin{array}{l}3.59 \pm \\
0.60\end{array}$ & - & - & - & - & - & - \\
\hline Glabella & $\begin{array}{l}5.51 \pm \\
1.29\end{array}$ & $\begin{array}{l}5.49 \pm \\
1.48\end{array}$ & $\begin{array}{l}5.18 \pm \\
0.66\end{array}$ & $\begin{array}{l}5.24 \pm \\
0.74\end{array}$ & $\begin{array}{l}5.43 \pm \\
0.71\end{array}$ & $\begin{array}{l}5.32 \pm \\
056\end{array}$ & 6.28 & 6.01 & $\begin{array}{l}6.02 \pm \\
1.1 .32\end{array}$ & $6.30 \pm 1.17$ & $6.89 \pm 1.82$ & $\begin{array}{l}5.35 \pm \\
0.93\end{array}$ \\
\hline Nasion & $\begin{array}{l}6.84 \pm \\
1.94\end{array}$ & $\begin{array}{l}5.87 \pm \\
1.47\end{array}$ & $\begin{array}{l}5.86 \pm \\
0.65\end{array}$ & $\begin{array}{l}5.76 \pm \\
0.76\end{array}$ & $\begin{array}{l}4.44 \pm \\
0.67\end{array}$ & $\begin{array}{l}4.15 \pm \\
066\end{array}$ & 7.34 & 7.14 & $\begin{array}{l}8.26 \pm \\
1.87\end{array}$ & $9.42 \pm 1.91$ & $6.89 \pm 1.42$ & $\begin{array}{l}4.99 \pm \\
1.03\end{array}$ \\
\hline Rhinion & $\begin{array}{l}2.89 \pm \\
2.00\end{array}$ & $\begin{array}{l}2.65 \pm \\
1.25\end{array}$ & $\begin{array}{l}2.07 \pm \\
0.11\end{array}$ & $\begin{array}{l}2.03 \pm \\
0.11\end{array}$ & $\begin{array}{l}2.64 \pm \\
052\end{array}$ & $\begin{array}{l}2.40 \pm \\
0.58\end{array}$ & 3.88 & 3.79 & $\begin{array}{l}2.62 \pm \\
0.63\end{array}$ & $3.12 \pm 0.63$ & $2.38 \pm 0.56$ & $\begin{array}{l}2.05 \pm \\
0.44\end{array}$ \\
\hline Mid-philtrum & $\begin{array}{l}12.62 \pm \\
2.78\end{array}$ & $\begin{array}{l}9.81 \pm \\
2.58\end{array}$ & $\begin{array}{l}11.84 \pm \\
1.19\end{array}$ & $\begin{array}{l}10.68 \pm \\
1.56\end{array}$ & $\begin{array}{l}10.35 \pm \\
1.20\end{array}$ & $\begin{array}{l}9.04 \pm \\
1.03\end{array}$ & 14.88 & 12.38 & - & - & $\begin{array}{l}10.09 \pm \\
1.55\end{array}$ & $\begin{array}{l}10.32 \pm \\
1.15\end{array}$ \\
\hline $\begin{array}{l}\text { Upper lip } \\
\text { margin }\end{array}$ & $\begin{array}{l}10.72 \pm \\
3.52\end{array}$ & $\begin{array}{l}8.40 \pm \\
2.87\end{array}$ & $\begin{array}{l}10.44 \pm \\
1.21\end{array}$ & $\begin{array}{l}10.01 \pm \\
1.13\end{array}$ & $\begin{array}{l}11.75 \pm \\
1.62\end{array}$ & $\begin{array}{l}10.52 \pm \\
1.23\end{array}$ & 14.56 & 11.61 & $\begin{array}{l}11.13 \pm \\
1.97\end{array}$ & $13.71 \pm 2.69$ & $\begin{array}{l}12.52 \pm \\
1.92\end{array}$ & $\begin{array}{l}10.28 \pm \\
1.66\end{array}$ \\
\hline $\begin{array}{l}\text { Lower lip } \\
\text { margin }\end{array}$ & $\begin{array}{l}9.82 \pm \\
2.71\end{array}$ & $\begin{array}{l}8.41 \pm \\
2.63\end{array}$ & $\begin{array}{l}11.56 \pm \\
0.96\end{array}$ & $\begin{array}{l}11.07 \pm \\
1.23\end{array}$ & $\begin{array}{l}12.48 \pm \\
1.30\end{array}$ & $\begin{array}{l}11.13 \pm \\
1.21\end{array}$ & 14.25 & 12.09 & $\begin{array}{l}14.15 \pm \\
1.96\end{array}$ & $16.35 \pm 2.10$ & $\begin{array}{l}15.05 \pm \\
1.99\end{array}$ & $\begin{array}{l}12.27 \pm \\
1.80\end{array}$ \\
\hline $\begin{array}{l}\text { Mental } \\
\text { eminence }\end{array}$ & $\begin{array}{l}10.38 \pm \\
2.62\end{array}$ & $\begin{array}{l}8.95 \pm \\
2.43\end{array}$ & $\begin{array}{l}8.95 \pm \\
1.22\end{array}$ & $\begin{array}{l}8.85 \pm \\
1.22\end{array}$ & $\begin{array}{l}10.35 \pm \\
1.19\end{array}$ & $\begin{array}{l}9.33 \pm \\
1.09\end{array}$ & 12.26 & 10.8 & $\begin{array}{l}10.94 \pm \\
1.42\end{array}$ & $12.51 \pm 1.56$ & $\begin{array}{l}11.25 \pm \\
2.14\end{array}$ & $\begin{array}{l}10.64 \pm \\
1.91\end{array}$ \\
\hline Gnathion & $\begin{array}{l}6.82 \pm \\
2.90\end{array}$ & $\begin{array}{l}5.63 \pm \\
2.76\end{array}$ & $\begin{array}{l}7.47 \pm \\
1.13\end{array}$ & $\begin{array}{l}6.65 \pm \\
1.15\end{array}$ & $\begin{array}{l}5.57 \pm \\
1.03\end{array}$ & $\begin{array}{l}5.36 \pm \\
1.01\end{array}$ & 7.25 & 12.36 & $\begin{array}{l}7.98 \pm \\
2.16\end{array}$ & $9.15 \pm 1.88$ & $6.99 \pm 1.61$ & $\begin{array}{l}6.23 \pm \\
1.24\end{array}$ \\
\hline
\end{tabular}

Chen et al. ${ }^{[18]}$ estimated craniofacial soft tissue thickness and nasal profile of 425 Chinese subjects from 31 landmarks using MRI scans and reported that males had significantly more values of FSTT than females at most landmarks. Munoz et al. ${ }^{[21]}$ analyzed asymmetry in FSTT at six bilateral Cephalometric landmarks of 32 adult Spanish corpses and found no significant sex and side differences in tissue symmetries. $\mathrm{Ca}$ vanaugh and Steyn ${ }^{[22]}$ estimated FSTT values at 28 facial landmarks of South African females and concluded that individuals from different geographical areas have different facial features and hence different soft tissue thicknesses. Ruiz ${ }^{[23]}$ estimated facial soft tissue thickness at 17 anatomical landmarks of Columbian adults and found no sexual dimorphism in FSTT, though midline landmarks showed some differences. Fernandez et al. ${ }^{[24]}$ conducted a comparative study of soft tissue thickness in Japanese, Mongoloids and Caucasoid subjects and found significant differences between two sexes and in different races at different anthropological facial landmarks.

Cho ${ }^{[25]}$ measured soft tissue thickness of South Korean adults with normal facial profiles and reported that STT at different facial areas in two sexes are different and reported that orthodontists should use different therapeutic approach for each sex. Pithon et al. ${ }^{[26]}$ estimated FSTT of Brazilian children using teleradiographs and found that rhinion, subnasal and upper lip show significant sexual dimorphism and all landmarks showed higher values than the Americans, Negroes and Hispanics. Hwang et al. ${ }^{[27]}$ prepared a database of soft tissue thickness for Korean adults and reported that mandibular region tissue thickness showed greater bilateral cephalometry which can be effectively used for forensic craniofacial reconstructions. Sfroza et al. ${ }^{[28]}$ provided sexand age-related soft tissue dimensions of orbital region in a Sudanese population to be used for forensic purposes like evaluations of traumas, craniofacial alterations, facial reconstructions, ageing of living and dead people. Guyomarch et al. ${ }^{[29]}$ investigated variability in facial soft tissue depths of French adults collected from 37 landmarks on 500 CT (computed tomography) scans and found negligible variations with sex, though corpulence was found significantly correlated with FSTT. Statistically significant differences have been reported in facial tissue depths of different races. ${ }^{[30]}$ All such studies show significant differences in tissue thicknesses of individuals of different population groups and thus signify the need for population specific standards for soft tissue thickness assessments. 
Knowledge of facial soft tissue thickness is useful not only for forensic purposes but also utilized to locate in-depth penetration of facial tumors (malignant or non-malignant), no-ablative dermal laser therapy and anthropological reconstruction of ancient people. To provide cranial and tissue depth standards to plan and execute reconstructive surgeries by orthopedicians or surgeons to treat any congenital or posttraumatic facial disharmonies. Aesthetic appraisal of adult faces depends upon combinations of averages, symmetry, neoteny, youthfulness and sexual dimorphism. Prediction of sex and age dependent changes in the craniofacial complex is becoming increasingly important for forensic facial reconstructions. Tissue depths give limited information about the skull shape and architecture of body structures which influence facial appearance. Soft-tissue thicknesses differ in two sexes of different ethnic groups and at different ages of life. So standards developed for different parts of globe and at different times cannot be reproduced for other parts. Sexual dimorphism in tissue depths have been reported, though such differences are small1 and pooled data of all sources reflect very little differences between two sexes, though it has been reported more in males than females.

\section{Conclusions}

The tissue depths estimated from MRI and CT scans showed sexual dimorphism at most of craniofacial landmarks and these points differ in two imaging modalities. The MRI based FSTT estimates provided comparatively higher accuracy levels for sex estimations than the CT scans. BMI showed no significant sexual differences in tissue depth estimates and a more comprehensive study is underway to arrive at some valid conclusions about relationship between BMI and facial soft tissue thicknesses. Present study subjects had higher tissue depths at few facial landmarks than the studies conducted by Sahni et al. ${ }^{[11,12]}$ on the same population about one and half decade earlier. Present study findings are expected to provide some help to experts of different medical disciplines like anatomists, orthopedicians, orthodontics, ophthalmologists, surgeons (particularly plastic surgeons), otolaryngologists, and dermatologists who deal with facial anatomies of the patients on daily routine basis. The softtissue estimates of the proposed extensive study may also help forensic anthropologists in cranio-facial reconstructions by understanding the intricate relationship between physiognomic/morphological features, bony skull contour and the depths of underlying soft tissues. ${ }^{[31,32]}$ The present study results can be correlated with other radio-diagnostic modalities (like ultrasound or X-rays) in future studies to suggest some valid standards of soft-tissue tissue thickness at different cephalometric landmarks on face. Present study standards may also help the security agencies to scan and match facial images of some fugitive criminals to prevent their entries to higher strategic surveillance locations like airports, defence stations, atomic reactors, space stations etc.

\section{ACKNOWLEDgements}

Authors are deeply indebted to those subjects whose MRI and CT scan analyses formed the basis of present research investigation. The financial support provided in the form of 'BSR-Start-Up Grant' by UGC, New Delhi vide Grant No. F.30-54/2014 (BSR) helped corresponding author in preparation of this research article.

\section{CONFlicts of InTEREST Disclosure}

The authors have no conflict of interest related to this publication.

\section{REFERENCES}

[1] Rhine JS, Campbell HR. Thickness of facial tissues in American blacks. J Forensic Sci. 1980; 25: 847-858. PMid:7430993 https://doi.org/10.1520/JFS11301J

[2] De Greef S, Cloes P, Vandermculen D, et al. Large scale in-vivo Caucasian facial soft tissue thickness database for craniofacial reconstructions. Forensic Sci Int. 2006; 159S: 126-146. PMid:16563680 https://doi.org/10.1016/j.forsciint.2006.02.034

[3] Domaracki M, Stephan CN. Facial soft tissue thicknesses in Australian Adult Cadavers. J Forensic Sci. 2006; 51(1): 5-10. PMid:16423216 https://doi .org/10.1111/j.1556-4029. 20 05.00009.x

[4] Baydas B, Erdem A, Yavuz I, et al. Heritability of facial proportions and soft tissue profile: characteristics in Turkish Anatolian siblings. Am J Orthod Dentofacial Orthop. 2007; 131: 504-509. PMid:17418717 https://doi.org/10.1016/j . ajodo. 2005.0 5.055

Published by Sciedu Press
[5] Krogman WM, Iscan MY. The Human Skeleton in Forensic Medicine; 2nd ed., Charles C Thomas, Springfield. 1986. 413-457 p.

[6] Wilkinson C. Forensic Facial Reconstruction, Cambridge University Press, Cambridge. 2004. 114-119, 124-156 p. https://doi.org/ 10.1017/СB09781107340961

[7] Nagle E, Teibe U, Kapoka D. Craniofacial anthropometry in a group of healthy Latvian residents. Acta Medica Lituanica. 2005; 12: 47-53

[8] Lie HC, Rhodes G, Simmons LW. Genetic diversity revealed in human faces. Evol. 2008; 62: 2473-2486. PMid:18691260 https: //doi.org/10.1111/j.1558-5646.2008.00478.x

[9] Jia L, Qi B, Yang J, et al. Ultrasonic measurement of facial tissue depth in a Northern Chinese Han population. Forensic Sci Int. 2016; 247: e.1-e.6.

[10] Kotrashetti VS, Mallapur MD. Radiographic assessment of facial soft tissue thickness in South Indian population-an anthropologic study. J Forensic Leg Med. 2016; 39: 161-168. PMid:26924726 https://doi.org/10.1016/j.jflm.2016.01.032 
[11] Sahni D, Jit I, Gupta M, et al. Preliminary study on facial soft tissue thickness by magnetic resonance imaging in northwest Indians. Forensic Sci Commun. 2002; 4: 1-7.

[12] Sahni D, Sanjeev, Singh G, et al. Facial soft tissue thickness in northwest Indian adults. Forensic Sci Int. 2008; 176: 137-146. PMid:17997243 https://doi.org/10.1016/j.forsciint. 20 07.07 .012

[13] Hillewig E, Degroote J, Van der Paelt T, et al. Magnetic resonance Imaging of the sterna extremity of clavicle in forensic ageestimations: towards more sound age estimations. Int J Leg Med. 2013; 127: 677-689. PMid:23224029 https ://doi .org/10.100 7/s00414-012-0798-z

[14] Seidler H, Falk D, Stringer C, et al. A comparative study of stereolithographically modelled skulls of Petralona and Broken Hill: implications for future studies of middle pleistocene hominid evolution. J Human Evol. 1997; 32: 375-378. https : //doi.org/10.1006/ jhev. 1997.0163

[15] IBM SPSS Statistics for Windows, Version 21.0, Armonk, NY: IBM Corp; 2012.

[16] Sachan A, Srivastava A, Chaturvedi TP. Soft tissue Cephalometric norms in a North Indian ethnic population. J Orthodont Surg. 2012; 1: 92-97. PMid:24987634 https ://doi.org/10.4103/2278-0 203.105877

[17] Saxena T, Panat SR, Sangamesh NC, et al. facial soft tissue thickness in north Indian population. J Ind Acad Oral Med Radiol. 2012; 24: 121-124. https://doi.org/10.5005/jp-journals-100 11- 1275

[18] Chen F, Chen Y, Yu Y, et al. Age and sex related measurement of craniofacial soft tissue thickness and nasal profile in the Chinese population. Forensic Sci Int. 2011; 212: 272 e.1-e.6.

[19] Sipahioglu S, Ulubay H, Diren HB. Midline facial soft tissue thickness database of Turkish population: MRI study. Forensic Sci Int. 2012; 219: 282 e.1-e.8

[20] Drgacova A, Dupej J, Veleminska J. Facial soft tissue thickness in present Czeck population. Forensic Sci Int. 2016; 260: 106e.1-e.7.

[21] Munoz SRT, Cantin M, Rozas JFR, et al. Estimation of facial asymmetry using soft tissue thickness for forensic purposes. Int J Morphol 2011; 29: 1033-1039. https://doi.org/10.4067/S0717-950 22011000300063
[22] Cavanaugh D, Steyn M. Facial reconstruction values for South African black females. Forensic Sci Int. 2011; 206: 215 e.1-215 e.7.

[23] Ruiz NAP. Facial soft-tissue thickness of Columbian adults. Forensic Sci Int. 2013; 229: 160 e.1-160 e.9.

[24] Fernandez TMF, Pinzan A, Sathler R, et al. Comparative study of the soft tissue of young Japanese-Brazilian, Caucasian and Mongoloid patients. Dent Press J Orthod. 2013; 18: 116-124. https : //doi.org/10.1590/S2176-94512013000200023

[25] Cho KS. Soft tissue thickness of South Korean adults with normal facial profile. Korean J Orthod. 2013; 43: 178-185. PMid:24015387 https ://doi.org/10.4041/kjod.2013.43.4.178

[26] Pithon MH, Santos RL, Ribeiro DR, et al. Soft tissue thickness in young North Eastern Brazilian individuals with different skeletal classes. J Forensic Leg Med. 2014; 22: 115-120. PMid:24485435 https://doi.org/10.1016/j.jflm.2013.09.014

[27] Hwang HS, Park MK, Lee WJ, et al. Facial soft tissue database for craniofacial reconstruction in Korean adults. J Forensic Sci. 2012; 57: 1442-1447. PMid:22621203 https://doi.org/10.1111/j. 1556-4029.2012.02192.x

[28] Sfroza C, Elamin F, Tommasi DG, et al. Morphometry of soft tissues of the orbital region in the Northern Sudanese persons. Forensic Sci Int. 2013; 228: 180e.1-180e.11.

[29] Guyomarch P, Santos F, Dutailly B, et al. Facial soft tissue depths in French adults: Variability, specificity and estimation. Forensic Sci Int 2013; 231(411): e1-e11. https://doi.org/10.1016/j.forsci int. 2013.04 .007

[30] Pickering R, Bachman D. The uses of forensic anthropology. CRC Press; New York: 1997.

[31] Starbuck JM, Ward RE. The affect of tissue depth variation on craniofacial reconstructions. Forensic Sci Int. 2007; 172: 130-136. PMid:17353107 https://doi.org/10.1016/j.forsciint. 20 07.01 .006

[32] Hatipoglu HG, Ozcan HN, Hatipoglu US, et al. Age, sex and body mass index in relation to calvarial dipole thickness and craniometric data on MRI. Forensic Sci Int. 2008; 182: 46-51. PMid:18996658 https ://doi.org/10.1016/j.forsciint.2008.09.014 